НАУКОВИЙ ВІСНИК

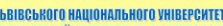

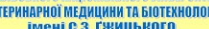
імені с.3.гжицьког Scientific messenger of L Lviv National University of
veterinary Medicie and Biotechnolggies

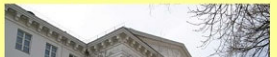
II If 1 is III) F.

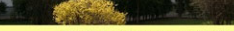

СЕРЯЯ "ЕКОНОМІЧНА НАУКИ" Том 21 № 93 2019

\section{Науковий вісник Дьвівського національного університету} ветеринарної медицини та біотехнологій імені С.3. Гжицького. Серія: Економічні науки

\author{
Scientific Messenger of Lviv National University \\ of Veterinary Medicine and Biotechnologies. \\ Series: Economical Sciences
}

\title{
Some aspects of the development of management science in Ukraine
}

\author{
M. Shulskyi
}

Stepan Gzhytskyi National University of Veterinary Medicine and Biotechnologies Lviv, Ukraine

Article info

Received 09.09.2019

Received in revised form 07.10 .2019

Accepted 08.10.2019

Stepan Gzhytskyi National University of Veterinary Medicine and Biotechnologies Lviv, Pekarska Str., 50, Lviv, 79010, Ukraine.

Tel.: +38-097-569-77-12 E-mail:Pretty62@ukr.net
Shulskyi, M. (2019 Some aspects of the development of management science in Ukraine. Scientific Messenger of Lviv National University of Veterinary Medicine and Biotechnologies. Series: Economical Sciences, 21(92), 35-41. doi: 10.32718/nvlvet-e9308

The article studies the development of managerial science in Ukraine over a long historical period. Special attention was paid to the development of this field of knowledge in the XX century. In the process of research, the main focus is on the achievements of those researchers who conducted the study and establishment of certain laws of management science development in Ukraine, and their research results are reflected in the educational literature, which is widely used in the training of professionals in both management and other professional-oriented specialists in various fields of activity. Such symbiosis in combining the results of research and bringing them to the training of student youth allows to carry out their teaching in the basics of managerial science most effectively and efficiently. The presentation of the material is carried out in a logical sequence using the dialog method of research. The results of the studies are presented in tabular form, which allowed them to clarify in detail and increase their level of perception both by those who study and research the development of management science, and those who show some interest in its functioning.

Key words: management science, development, research, management, results, administrative command system, reforms.

\section{Деякі аспекти розвитку науки управління в Україні}

\author{
М.Г. Шульський
}

Львівський національний університет ветеринарної медицини та біотехнологій імені С.3. Гжсицкого, м. Львів, Україна

Проведено дослідження розвитку управлінської науки в Україні протягом тривалого історичного періоду. При цьвому особливу увагу скониентровано на розвитку иієї галузі знань у XX столітті. В прочесі досліджень основний акиент зроблено на здобутках тих дослідників, які проводили вивчення і встановлення певних закономірностей розвитку науки управління в Україні, а результати їхніх досліджень відображені у навчальній літературі, що широко використовується при підготовиі фахівців як $з$ менеджменту, так $і$ з інших професійно-орієнтованих спеціалістів у різноманітних сферах діяльності. Такий симбіоз у поєднанні результатів досліджень і доведення їх до підготовки студентської молоді дозволяє найбільш ефективно і результативно проводити навчання основам менеджерської науки. Виклад матеріалу проведено у певній логічній послідовності з використанням діалогового методу досліджень. Результати досліджень відображені у табличних формах, шзо дозволило їх детально унаочнити і підвищити рівень їхнього сприйняття як тими, хто займається вивченням і дослідженням розвитку управлінської науки, так і тими, хто проявляє певний інтерес до ї̈ функціонування.

Ключові слова: наука управління, розвиток, дослідження, менеджмент, результати, адміністративно-командна система, реформи. 


\section{Вступ}

Розвиток людського суспільства на зламі століть і особливо при переході від одного тисячоліття до іншого характеризується кардинальними змінами в усіх сферах суспільних відносин. Ці глобальні зміни відбуваються на всіх земних континентах, а, можливо, і поза ними, адже нічого і ніде не піддається сталістю розвитку. 3 цього приводу ми дотримуємося твердження, що розвиток ніколи і за будь-яких обставин не може бути сталим. Якщо він сталий, то це не є розвиток. Такі твердження не $є$ випадковістю, а реальними і об'єктивними закономірностями, що обумовлені діючими законами діалектики. Це у найбільшій мірі характерне для людських відносин, важливою складовою яких $є$ взаємовідносини між людьми, які відображаються в здійсненні управлінської діяльності у процесах функціонування людського суспільства.

У світовому просторі, а в ньому кожна країна проходила, проходить і буде проходити в майбутньому певні зміни у своїй діяльності, особливою складовою серед яких $є$ здійснення управлінської діяльності у різних сферах суспільних відносин. Враховуючи вищесказане, нами поставлено за мету прослідкувати, як процеси управління розвивались в Україні? Це, безумовно, надто складне, неоднозначне і багатовекторне завдання, вирішенню якого присвячені праці багатьох поколінь вітчизняних науковців як державного, так і регіонального рівнів. Цілком зрозуміло, що розглянути всі напрацювання представників науки управління минулих поколінь у цій публікації практично неможливо як 3 теоретичних поглядів, так і практичних надбань. 3 врахуванням складності проведення досліджень із вищезгаданих проблем цілком закономірно виникло питання, а як проводити їх вивчення у просторі і часі? Для розв'язання вказаних проблем можна використовувати різні напрями, методи і підходи. Ми в основу наших досліджень використали один із них, а саме: наукові здобутки деяких вчених з менеджменту, які, на наше переконання, найбільш повно відобразили розвиток науки управління в Україні, і дещо спрогнозували іiі розвиток на майбутнє. Все це в комплексі дозволило виконати поставлені завдання і на основі цього досягти поставленої мети.

\section{Матеріал і методи досліджень}

Виконання обсягів намічених завдань забезпечувалося шляхом використання матеріалів досліджень вітчизняних науковців, праці яких у тих чи інших напрацюваннях та вимірах мали пряму, а інколи й опередковану причетність до обраної теми наукових досліджень. При цьому нами надано перевагу тим авторам, які результати своїх досліджень відображали у навчально-методичних джерелах (підручниках, посібниках та інших джерела навчального характеру). Такий підхід дозволяє найповніше використовувати надбання управлінської науки безпосередньо у практичних цілях, а згодом це стане тим фундаментом, тією основою для наступних поколінь науковців, метою яких буде дослідження розвитку управлінської науки не тільки в Україні, а й за ії межами.
У процесах дослідження використовувались різноманітні методи економічних досліджень, кожен 3 яких відігравав ті чи інші ролі та мав значення для реалізації сформованих завдань і досягнення поставлених цілей. При цьому зауважимо, що пріоритетне значення для розкриття теми передбачених досліджень було надано діалоговому методу дослідження. Його суть полягає в тому, що нами були сформовані конкретні найбільш актуальні питання щодо розкриття теми обраного наукового дослідження, а відповіді використано із літературних джерел. Саме такий підхід дозволив найповніше поєднати запити суспільства 3 питань розвитку науки управління, з одного боку, та отримати конкретизовані відповіді на їх задоволення -3 іншого.

\section{Результати та їх обговорення}

Розвиток будь-яких сфер суспільного виробництва характеризується певними результатами їх функціонування, які слід постійно, всебічно i, що головне, об'єктивно досліджувати. Це необхідно для того, щоб врахувати те, чого досягнуто чи не вдалося досягти, однак було намічено і були настирливі прагнення забезпечити їх виконання, проте не вдалося досягти передбаченого. Причин недосягнення наміченого $€$ цілий комплекс таких, які залежать від людського фактору і тих, які є за межами його впливу. Однак у будь-яких діях і діяльності досягаються певні результати, які необхідно обговорювати і давати об'єктивні оцінки як досягнутого, так і того, що не вдалося досягти, хоча були докладені чималі зусилля. Звідси цілком закономірно постає питання, а для чого і кому це потрібно? Питання цілком слушне i, можна сказати, у певній мірі вмотивоване. Передовсім це необхідно для того, щоб усунути те, що гальмує розвиток тієї чи іншої насамперед управлінської діяльності, з одного боку, та не повторення їх у майбутньому - з іншого.

У даній публікації, як було зазначено раніше, передбачено дослідити розвиток науки управління в Україні. Ці процеси зазвичай аналізують 3 початку тих років, коли Україна перебувала у складі Російської імперії, в Радянському Союзі, а згодом як незалежна держава. 3 цього приводу варто також зауважити, що деякі науковці поглиблюють свої дослідження 3 періодом функціонуванням Київської Русі. Проте, як стверджують науковці, обгрунтування науки управління проводилось у значно пізні періоди історичного розвитку людства. Насамперед згадують Шумерську державу в III-му тисячолітті до нашої ери, в якій “існував певний регламент управлінської діяльності, пов'язаний 3 комерційними операціями і управління державою. Це було зафіксовано на глиняних табличках, що дійшли до наших днів" (Zavadskyi, 1998). В об'єктивності цих висловлювань немає сумнівів, проте варто взяти до уваги, що на території сучасної України існувала держава Аратта. Це підтверджують: написи Кам'яної Могили, які є “свідченням про те, що саме на теренах сучасної України близько 6200 р. до н. е. склалася найперша у світі держава - Аратта, яка мала свої фортеці, канали, професійних священиків та 
воїнів, суспільну ієрархію, певні ритуали і культи та міфологію. Це була найдавніша хліборобська держава" (Ostafiichuk, 2006).

Отож питання щодо виникнення управлінської діяльності на різних ієрархічних рівнях і в різні періоди існування людства до кінця ще не вивчені й тому 3'ясування цих проблем вимагають подальшого дослідження. Залишимо це все тим, хто причетний до розв'язання цих проблем, а ми повернемося до суті досліджень за обраною темою. Питанням розвитку науки управління в Україні присвячені праці багатьох дослідників, серед яких вирізняється праця професора Ф.I. Хміля (Khmil, 2003), матеріали якої нами покладено в основу наших досліджень. Вивчення результатів проведено у такій послідовності, в якій подано вченим.

\section{Таблиця 1}

Внесок українських вчених у розвиток світової науки менеджменту в дореволюційний період (Khmil, 2003)
Приступаючи до реалізації поставлених завдань, Ф.І. Хміль стисло охарактеризував складність вивчення історії розвитку науки управління в Російській імперії, а згодом - у Радянському Союзі. Це показано у відповіді на перше питання таблиці 1. Зі свого боку додамо, що процеси переміщення вчених із провінції у столиці держав чи в їхні великі міста характерні не тільки для царської Росії чи Радянського Союзу, а й для майже всіх країн світового простору. Підтвердженням сказаного може бути французька приказка: "Генії народжуються у провінції, а вмирають в Парижі”. Переміщення наукових кадрів у прямому і зворотному напрямах, на переконання Ф.І. Хміля, “забезпечувало загалом позитивну взаємну дифузію наукових шкіл і поглядів” (Khmil, 2003).

\begin{tabular}{|c|c|c|}
\hline $\begin{array}{l}\text { № } \\
\text { П/ח }\end{array}$ & Питання, сформовані нами & Відповіді з тексту вищеназваного джерела \\
\hline 1 & $\begin{array}{l}\text { Що обумовлювало складність вивчення } \\
\text { української управлінської науки? }\end{array}$ & $\begin{array}{l}\text { Вивчення історії розвитку української управлінської думки в умовах Росій- } \\
\text { ської імперії, а пізніше - Радянського Союзу є складною проблемою внаслі- } \\
\text { док фізичного переміщення вчених українського походження в інші регіони } \\
\text { Росії та СРСР і зворотного процесу }\end{array}$ \\
\hline 2 & $\begin{array}{l}\text { Хто був найпомітнішою постаттю серед } \\
\text { тих, хто стояв біля витоків управлінсь- } \\
\text { кої науки в Україні? }\end{array}$ & $\begin{array}{l}\text { Серед тих, хто стояв біля витоків української управлінської науки, най- } \\
\text { помітнішою постаттю є всесвітньо відомий український економіст Ми- } \\
\text { хайло Іванович Туган- Барановський (1865-1919) }\end{array}$ \\
\hline 3 & $\begin{array}{l}\text { Що охоплювали наукові уподобання } \\
\text { М.І. Туган-Барановського? }\end{array}$ & $\begin{array}{l}\text { Його наукові уподобання охоплювали макро- і мікроекономічну пробле- } \\
\text { матику, економічну психологію, соціальну економіку. Проблеми управ- } \\
\text { ління народним господарством фігурують у більшості його наукових } \\
\text { праць }\end{array}$ \\
\hline 4 & $\begin{array}{l}\text { Яка праця принесла М.I. Туган- } \\
\text { Барановському міжнародне визнання? }\end{array}$ & $\begin{array}{l}\text { Міжнародне визнання здобула публікація магістерської дисертації “Про- } \\
\text { мислові кризи в сучасній Англії, їх причини і близький вплив на народне } \\
\text { життя”, пізніше перевидано багатьма мовами }\end{array}$ \\
\hline 5 & $\begin{array}{l}\text { Хто продовжував працювати над про- } \\
\text { блемами, що були порушені М.I. Туган- } \\
\text { Барановським? }\end{array}$ & $\begin{array}{l}\text { Над теорією капіталістичних криз та іншими проблемами, порушеними в } \\
\text { працях М. Туган-Барановського, продовжували працювати англійські } \\
\text { економісти Артур-Сесіл Пігу (1877-1959), Джон-Мейнард Кейнс (1883- } \\
\text { 1946), Джон Хікс (1904-1989), німецькі політичні діячі Карл Каутський } \\
\text { (1854-1938), Роза Люксембург (1871-1919), Едуард Бернштейн (1850- } \\
\text { 1932), американський економіст Йозеф Шумпетер (1883-1950) }\end{array}$ \\
\hline 6 & $\begin{array}{l}\text { Яке визнання мала теорія капіталістич- } \\
\text { них криз, що обгрунтована М.I. Туган- } \\
\text { Барановським? }\end{array}$ & $\begin{array}{l}\text { Попри те, вона здобула не тільки теоретичне визнання, а й практичне } \\
\text { застосування. Так, у } 1912 \text { р. у Франції на основі цієї теорії був створений } \\
\text { постійний комітет для передбачення промислових криз і відповідної } \\
\text { адаптації народного господарства }\end{array}$ \\
\hline 7 & $\begin{array}{l}\text { Який внесок в науку управління вніс } \\
\text { Є.Є. Слуцький? }\end{array}$ & $\begin{array}{l}\text { Значний внесок у світову науку управління зробив український еконо- } \\
\text { міст і математик Євген Євгенович Слуцький (1880-1946), якого можна } \\
\text { вважати засновником математичного моделювання економічних та } \\
\text { управлінських процесів, а також праксеології (грец. Praxis - справа) }\end{array}$ \\
\hline 8 & $\begin{array}{l}\text { Що обгрунтував український вчений } \\
\text { М.П. Яснопольський? }\end{array}$ & $\begin{array}{l}\text { Український вчений Микола Петрович Яснопольський (1846-1937) об- } \\
\text { грунтував теорію місцевого самоврядування на основі диференційовано- } \\
\text { го врахування економічної продуктивності територій }\end{array}$ \\
\hline 9 & $\begin{array}{l}\text { Які ще українські вчені досліджували } \\
\text { управлінську проблематику? }\end{array}$ & $\begin{array}{l}\text { Управлінську проблематику досліджували українські історики Володи- } \\
\text { мир Боніфатійович Антонович (1834- 1908), Михайло Петрович Драго- } \\
\text { манов (1841-1895), Максим Максимович Ковалевський (1851-1916), } \\
\text { економісти Микола Іванович Зібер (1844-1888), Григорій Матвійович } \\
\text { Цехановський (1833-1898), юрист та громадський діяч Кость Левицький } \\
(1859-1941), \text { педагог Антон Семенович Макаренко (1888-1939) }\end{array}$ \\
\hline 10 & $\begin{array}{l}\text { Яке значення мали результати дослі- } \\
\text { джень українських вчених? }\end{array}$ & $\begin{array}{l}\text { Дослідження українських учених-управлінців цього періоду мали не тільки } \\
\text { утилітарне значення для вдосконалення систем управління в царській } \\
\text { Росії, а й стали суттєвим внеском у розвиток світової теорії управління }\end{array}$ \\
\hline 11 & Що було започатковано у цей період? & $\begin{array}{l}\text { Тоді були започатковані основи української національної наукової шко- } \\
\text { ли управління, принципові засади якої реалізують сучасні вітчизняні } \\
\text { вчені }\end{array}$ \\
\hline
\end{tabular}


Серед науковців, які в тій чи іншій мірі були причетними до розвитку управлінської науки у ії світовому вимірі, Ф.І. Хміль вирізняє Михайла Івановича Туган-Барановського (1865-1919), називаючи його найпомітнішою постаттю і всесвітньо відомим економістом (відповідь на 2-ге питання). Безумовно, підстав для таких тверджень $є$ більше, ніж достатньо. На це, варто зауважити, вказувала ціла плеяда як українських, так і зарубіжних вчених. До речі також нагадати, що співробітниками кафедри менеджменту нашого університету у 2015 р. було проведено засідання круглого столу, в роботі якого взяли участь відомі вчені нашої держави. В їхніх доповідях охарактеризовано всебічну діяльність М.I. Туган-Барановського як на ниві науки, так і практичної управлінської діяльності (Rol i znachennia naukovoi spadshchyny..., 2015).

Аналізуючи діяльність М. Туган-Барановського, Ф. Хміль особливу увагу звертає на матеріали його магістерської дисертації, яка принесла йому міжнародне визнання (відповідь на 4-те питання). Над цією працею працювала ціла плеяда науковців різного спрямування 3 різних країн світу (відповідь на 5-те питання). Автор критичного підходив до оцінки діяльності, зокрема політичних діячів. Прикладом може бути оцінка діяльності В. Леніна, з яким він розходився “у поглядах на причини, симптоми виникнення та цикл відтворення промислових криз” (Khmil, 2003).

В роботі Ф.І. Хміля високо оцінено напрацювання 3 питань місцевого самоврядування М.П. Яснопольського на "основі диференційного врахування економічної продуктивності територій” (відповідь на 7-те питання). Досить також зауважити, що результати цих досліджень $є$ важливими і цінними в сучасних умовах подальшого розвитку процесів самоврядування у формуванні громад на основі децентралізації. Не обминув своєю увагою вчений і діяльність видатного українського економіста та математика С.С. Слуцького (помилкового названим в роботі Слупським - примітка М.Ш.). Про нього відзначив відомий дослідник української економічної думки С. Злупко: “Україна довго залишалася в боргу перед своїм талановитим сином. Тільки в умовах державної незалежності українські вчені почали вивчати творчу спадщину С. Слуцького" (Ukrainski kooperatory, 2001). Безперечно, такий стан був обумовлений діями різних чинників як внутрішнього, так і зовнішнього середовища. 3 цього приводу звернемося до відомої приповідки: “Краще зараз, ніж ніколи".

Характеризуючи діяльність трьох вищеназваних українських вчених на ниві управлінської діяльності, Ф.І. Хміль не обминув своєю увагою інших вчених України, праці яких присвячені розвитку науки управління. Не будемо наводити їхній перелік, адже вони згадані у відповіді на 9-те питання, а лише зазначимо, що здебільшого їхні дослідження були зосереджені на історико-економічній i конкретноприкладній проблематиці. Більшість праць орієнтувалися на пошук українських інституцій, традицій, які могли б стати основою побудови посткапіталістичного суспільства (Khmil, 2003). Яке це мало значення для розвитку науки управління? Відповідь дана в інформації на 10-те питання, а у відповіді на 11-те питання вказується на практично-прикладне значення результатів досліджень українських вчених у створенні національної школи управління, що має значення у сьогоднішніх умовах формування державної незалежності України.

Другою важливою складовою розвитку науки управління в Україні є іï перебування у складі Радянського Союзу, в якому намітився курс на побудову соціалізму. Загальні аспекти цього розвитку показано в таблиці 2. Для деталізації цих процесів Ф.І. Хміль подає їх у двох площинах, які практично не збігалися (відповідь на перше питання). Щодо першої площини, то тут була зосереджена наукова еліта, яка була нечисельною, однак дієвою. Вона мала пряму причетність до комуністичних партійних органів і держави та очолювала академічні наукові заклади (відповідь на 2ге питання). Які завдання виконували наукові працівники, що належали до складу цієї площини? Про це чітко сказано у відповіді на 3-те питання, в якому сконцентровано увагу на захист адміністративнокомандної системи. Досить відзначити, що відповіді на наступні питання, що подані в таблиці 2, в тій чи іншій мірі безпосередньо або опосередковано пов'язані з цією системою. Звідси цілком закономірно постає питання, а що являла собою адміністративнокомандна система, які функції вона виконувала, що захищала, на що були спрямовані іiі зусилля тощо?

У літературі управлінського спрямування в колишньому СРСР про неї майже не згадувалось, хоча елементи іiі діяли постійно, динамічно і безвідмовно.

В енциклопедичних виданнях після розпаду Радянського Союзу про цю систему сказано: “Адміністративно-командна система - система управління економікою країни, в якій вирішальна роль належить адміністративно-командним методам і влада зосереджується в руках бюрократичного апарату (партійного, радянського, господарського). Така характеристика системи відображає лише одну із сторін економічної системи, зокрема з боку господарського механізму" (Mochernyi, 2000).

Отож, ця система охоплювала всі складові різних суспільних відносин у державі. Основний леймотив іiі функціонування - "це команди зверху, виконання знизу”. І це доводилось у чітких формах та контролювалось різними методами і засобами впливу для виконання доведених завдань.

Коли перша група науковців (вищий рівень) займалася розв'язанням актуальних проблем на рівні держави, то друга була чисельнішою і вирішувала питання управління на рівні підприємств (відповідь на 4-ге питання) шляхом удосконалення організаційних структур і форм управління, методології досліджень, матеріального стимулювання тощо (відповідь на 5-6-те питання). Взаємозв'язок вчених з управлінської діяльності цих двох площин проявлявся в захисті адміністративно-командної системи, переміщення наукових кадрів з провінції у великі наукові центри (Москва, Ленінград) (відповіді на наступні питання). Одночасно зауважимо, що пристосування науковців до вимог діючої системи управління гальмувало ефективний розвиток теорії і практики здійснення управлінських процесів (відповідь на 9-те питання). 
Таблиця 2

Загальні аспекти розвитку науки управління в Україні в період існування СРCP (Khmil, 2003)

\begin{tabular}{|c|c|c|}
\hline $\begin{array}{l}\text { № } \\
\text { П/ח }\end{array}$ & Питання, сформовані нами & Відповіді з тексту вищеназваного джерела \\
\hline 1 & $\begin{array}{l}\text { Як відбувався розвиток науки управ- } \\
\text { ління у колишньому СРСР? }\end{array}$ & $\begin{array}{l}\text { У колишньому СРСР розвиток економічної науки, в тому числі науки } \\
\text { управління, відбувався у двох площинах, які практично не збігалися }\end{array}$ \\
\hline 2 & $\begin{array}{l}\text { Що являло собою перша площина } \\
\text { (вищий рівень)? }\end{array}$ & $\begin{array}{l}\text { У межах першої (вищий рівень) діяла нечисельна наукова еліта, яка на- } \\
\text { лежала до керівних органів комуністичної партії і держави, очолювала } \\
\text { академічні наукові заклади тощо }\end{array}$ \\
\hline 3 & Що було завданням цієї площини? & $\begin{array}{l}\text { Ïї завданням була апологетика (грец. apoloygigs - захист) командно- } \\
\text { адміністративної системи, розроблення концепцій економічного розвитку } \\
\text { i управління, спрямованих на підтримання та зміцнення існуючої соціа- } \\
\text { льно-економічної системи }\end{array}$ \\
\hline 4 & $\begin{array}{l}\text { Якими ознаками характеризувалась } \\
\text { група вчених, які працювали в межах } \\
\text { другої (низової) площини? }\end{array}$ & $\begin{array}{l}\text { Чисельнішою була група науковців, які працювали у межах другої (низо- } \\
\text { вої) площини і займалися вирішенням прикладних проблем управління на } \\
\text { рівні підприємств }\end{array}$ \\
\hline 5 & $\begin{array}{l}\text { Що удосконалювали науковці цієї } \\
\text { площини? }\end{array}$ & $\begin{array}{l}\text { Удосконалюючи організаційні структури і форми управління, методоло- } \\
\text { гію розроблення управлінських рішень, форми організації і стимулюван- } \\
\text { ня праці, методи планування і прогнозування, технологію, техніку і орга- } \\
\text { нізацію процесів управління }\end{array}$ \\
\hline 6 & $\begin{array}{l}\text { Які наукові пошуки проводили дослід- } \\
\text { ники і що впроваджували у практику та } \\
\text { їх актуальність? }\end{array}$ & $\begin{array}{l}\text { Вони проводили наукові пошуки й робили узагальнення, використовува- } \\
\text { ли сучасний науковий апарат, обгрунтовували і втілювали в практику } \\
\text { певні рекомендації, розробляли оригінальні підходи і методики, які не } \\
\text { втратили своєї актуальності й понині }\end{array}$ \\
\hline 7 & Чому спряли ці вчені? & $\begin{array}{l}\text { Ці вчені об’єктивно сприяли зміцненню адміністративно-командної сис- } \\
\text { теми, усуваючи її часткові недоліки, знаходячи шляхи (нехай тимчасово- } \\
\text { го) підвищення ефективності функціонування управління }\end{array}$ \\
\hline 8 & $\begin{array}{l}\text { В чому проявлялась особливість розви- } \\
\text { тку науки в СРСР? }\end{array}$ & $\begin{array}{l}\text { Особливістю розвитку науки в СРСР було постійне переміщення науко- } \\
\text { вих талантів } 3 \text { провінції в наукові центри - Москву та Ленінград, де були } \\
\text { кращі умови для наукової творчості і змога заявити про себе }\end{array}$ \\
\hline 9 & $\begin{array}{l}\text { Чому було відчутне відставання ефек- } \\
\text { тивності управління? }\end{array}$ & $\begin{array}{l}\text { Але відставання в теорії і особливо в практиці ефективного управління } \\
\text { було відчутним, оскільки управління радянськими організаціями протя- } \\
\text { гом десятиліть пристосовувалось до вимог адміністративно-командної } \\
\text { системи }\end{array}$ \\
\hline
\end{tabular}

При дослідженні функціонування управлінських систем у загальних аспектах їхнього функціонування, виникає об'єктивна необхідність їх проаналізувати в розрізі окремих періодів. 3 цього приводу зазначимо, що в оцінці цих проблем немає єдності думок серед дослідників. Так, М.М. Мартиненко проводить дослідження цих проблем, виділяючи 5-ть основних періодів (Martynenko, 2005), Ф.І. Хміль - 6-ть періодів (Khmil, 2003), дещо по-іншому підійшов до вирішення цих питань Й.С. Завадський (Zavadskyi, 1998). Для продовження подальших досліджень розвитку менеджменту в Україні нами використано матеріали досліджень Ф.І. Хміля. Оброблена певним чином інформація подана в таблиці 3.

3 методологічної точки зору нами використано діалоговий метод дослідження, який був застосований у попередніх складових даної публікації. При цьому для компактності подачі матеріалів в таблиці 3 інформація досліджень поділена на дві групи: періоди 3 1917 р. по 1945 р. відображені у вищезгаданій таблиці, а з 1946 р. по 1990 р. - у наступній таблиці 4. Такий підхід дозволяє, на наше переконання, оптимально вирішити два питання: більш унаочнено подати матеріали досліджень, з одного боку, та глибше вникнути в їхню суть - $з$ іншого.

3'ясувавши деякі особливості методології досліджень у цій публікації, повернемось до аналізу матеріалів, що подані у вищезгаданій таблиці 3. У відпові- ді на перше питання даної таблиці з'ясовано ті основні обставини, які зумовили необхідність виділення шести періодів розвитку науки управління у тодішньому СРСР. Україна, як відомо, була у складі цієї об’єднаної тоталітарної держави, і тому управлінська українська наука розвивалася у форматорі союзної науки управління. Ф.І. Хміль цілком зрозуміло і виправдано починає свою періодизацію розвитку управлінської науки з 1917 р., коли було повалено Тимчасовий уряд О.Ф. Керенського (188-1970) і закінчив 1921 р. Цей період був характерним тим, що відбувся злам найбільшої імперії у світі і “постало завдання побудови принципово нового суспільства". Однак у В. Леніна та його однодумців не було “чіткої програми державного устрою та системи організації управління економікою" (відповідь на друге питання). 3 точки зору діалектики революційний перехід від одного державно-політичного устрою до діаметрально протилежного вимагає здійснення корінних змін у всіх сферах суспільних відносинах. Наука управління у цих надто складних умовах займала особливе значення, адже необхідно було формувати нові управлінські структури на всіх ієрархічних рівнях управління новоствореною державою. I це необхідно було здійснювати як на рівні розвитку теоретичних обгрунтувань, так і на рівні їх реалізації безпосередньо у практичних умовах. 
Таблиця 3

Характерні особливості проведення наукових досліджень в СРСР у певні періоди розвитку держави (Кhmil, 2003)

\begin{tabular}{lll}
\hline $\begin{array}{c}\text { № } \\
\text { п/п }\end{array}$ & \multicolumn{1}{c}{ Питання, сформовані нами } & \multicolumn{1}{c}{ Відповіді з тексту вище назва джерела } \\
\hline 1 & Чим обумовлена необхідність виокрем- \\
лення окремих періодів у дослідженні \\
розвитку управлінської науки в СРСР?
\end{tabular}

Одночасно зазначимо, що теоретичні дослідження майже не розвивалися, проте інтенсивно проводились роботи щодо закладення основ “радянської управлінської науки”. Саме в цей період була сформовані основи “державного централізованого управління економікою” (відповідь на 3-тє питання таблиці 3). Досить також нагадати, що ті основи, які були закладені у фундаменті існування СРСР, 3 деякими пом'якшеннями протримались до закінчення його функціонування. Неабиякий інтерес у розвитку управлінської науки становить третій період (19291945 рр.), який характеризується розв'язанням питань прикладного характеру щодо розвитку різних галузей народного господарства. При цьому, що важливо, було привернено увагу до вивчення різноманітних методів здійснення управлінської діяльності (економічних, адміністративних, соціально-психологічних). Ці дослідження, до речі нагадати, проводяться донині. Такі напрями не втратили і не втратять актуальності як у сучасному, так і в майбутньому періодах проведення досліджень у розвитку науки управління.

Наведені вище періоди щодо проведення досліджень розвитку управлінської науки не вичерпують в повній мірі ії здійснення у наступні історичні періоди. Через ці обставини наведено інформацію про розвиток науки управління в наступних роках (табл. 4).

Таблиця 4 щодо подальшого розвитку менеджменту побудована на тих же принципах, що і таблиця 3. Різниця тільки в інформативному матеріалів, що в них подано і характеризується тими змінами, що відбувалися у різних сферах суспільних відносин. Саме тому ми не будемо деталізувати кожний період, що представлений у таблиці 4, а лише зазначимо, що ця інформація стала основою для подальшого розвитку менеджменту цих перетворень, що наведені в аналізуючій праці Ф.І. Хміля. Отож, автор зазначає що “зміни були започатковані в 1985 р. після приходу до влади М. Горбачова, який висунув ідею перебудови соціально-економічної системи та управління економікою” (Khmil, 2003). Яких результатів досягнуто в результаті перебудовчих процесів? Ми є свідками цих грандіозних змін і перемін, які необхідно глибоко і всебічно досліджувати 3 концентрацією особливої уваги на реформування управлінської діяльності у всіх сферах суспільних відносин. Проте відзначимо, що це тема нової наукової публікації. 


\section{Таблищя 4}

Характерні особливості розвитку науки управління у 1946-90-х роках (Khmil, 2003)

\begin{tabular}{|c|c|c|}
\hline $\begin{array}{l}\text { № } \\
\Pi / \Pi \\
\end{array}$ & Питання, сформовані нами & Відповіді з тексту вищеназваного джерела \\
\hline 1 & $\begin{array}{l}1946-1965 \text { рр. Якими змінами були } \\
\text { обумовлені нові підходи до управління і } \\
3 \text { якими факторами вони були пов'язані? }\end{array}$ & $\begin{array}{l}\text { IV. } 1946-1965 \text { рр. Ознаменований різкими змінами в управлінні народ- } \\
\text { ним господарством країни після смерті Сталіна в } 1953 \text { р. Вони були } \\
\text { пов'язані з посиленням матеріального стимулювання, вдосконаленням } \\
\text { оплати праці, задіянням товарно-грошових важелів, упорядкуванням цін, } \\
\text { особливо в сільському господарстві }\end{array}$ \\
\hline 2 & $\begin{array}{l}\text { Які пошуки в системі управління відбу- } \\
\text { лись у період “хрущовської відлиги”? }\end{array}$ & $\begin{array}{l}\text { У період “хрущовської відлиги” пошуки концентрувалися на формуванні } \\
\text { нових засад функціонування і взаємодії державних органів управління } \\
\text { шляхом переходу до територіальної і } \\
\text { територіально-галузевої системи управління }\end{array}$ \\
\hline 3 & $\begin{array}{l}\text { Яке ставлення до зарубіжної науки } \\
\text { управління, було в цей період? }\end{array}$ & $\begin{array}{l}\text { Значний інтерес викликали зарубіжні розробки дослідження операцій. } \\
\text { Впроваджувалася “математизація" наукових досліджень, в основному } \\
\text { для розроблення варіантів планових завдань }\end{array}$ \\
\hline 4 & $\begin{array}{l}\text { 1965-1975 рр. У чому полягала особли- } \\
\text { вість цього періоду у здійсненні ре- } \\
\text { форм? }\end{array}$ & $\begin{array}{l}\text { V } 1965-1975 \text { рр. Особливість його зумовлена спробою здійснити рефор- } \\
\text { му в народному господарстві, посиленням ролі економічних методів } \\
\text { управління }\end{array}$ \\
\hline 5 & Що мало стати основою реформ? & $\begin{array}{l}\text { Основою реформи мало стати запровадження господарського розрахунку } \\
\text { підприємств, елементи якого використовували ще в } 30 \text {-ті роки }\end{array}$ \\
\hline 6 & $\begin{array}{l}\text { Як проводилась реформа і } з \text { якими нас- } \\
\text { лідками вона закінчилася? }\end{array}$ & $\begin{array}{l}\text { Проводили наукові конференції, друкували багато різноманітних видань } \\
3 \text { проблем економічної реформи. Однак усі ці процеси не торкалися ко- } \\
\text { рінних засад соціально-економічної системи. В результаті реформа про- } \\
\text { валилася, а в економіці заявили про себе кризові явища, які призвели } \\
\text { згодом до розвалу Союзу }\end{array}$ \\
\hline 7 & $\begin{array}{l}\text { Що почалося визрівати у тогочасній } \\
\text { суспільній думці? }\end{array}$ & $\begin{array}{l}\text { VI 1975-1984 рр. У тогочасній суспільній думці почали визрівати ідеї } \\
\text { про необхідність радикальної зміни економічних відносин }\end{array}$ \\
\hline 8 & $\begin{array}{l}\text { Які були реалії тогочасного економічно- } \\
\text { го буття? }\end{array}$ & $\begin{array}{l}\text { Як реалії тогочасного економічного буття називались інфляція, падіння } \\
\text { темпів економічного розвитку, приховане безробіття, тіньова економіка } \\
\text { та ін. }\end{array}$ \\
\hline 9 & Як ці реалії здійснювалися в Україні? & $\begin{array}{l}\text { Правда, в Україні, де контроль партійно-державних і репресивних орга- } \\
\text { нів був значно сильнішим, такі теми публічно не обговорювалися }\end{array}$ \\
\hline 10 & $\begin{array}{l}\text { Що проводилось у 1985-1990 і які зміни } \\
\text { відбуваються в системі управління? }\end{array}$ & $\begin{array}{l}\text { Здійснювався інтенсивний пошук нових пріоритетів у формуванні еко- } \\
\text { номіки i держави. Системи управління вітчизняними виробничо- } \\
\text { господарськими організаціями перебувають на стадії становлення, відо- } \\
\text { бражаючи радикальні соціальні зміни у суспільстві }\end{array}$ \\
\hline
\end{tabular}

\section{Висновки}

На основі проведення дослідження розвитку менеджменту в Україні можна стверджувати, що в нашій державі накопичений чималий досвід функціонування управлінської діяльності у різних сферах суспільних відносин. Це підтверджується одержаними результатами досліджень, що наведені в таблицях 1-4 даної публікації, та конкретним їх аналізом. Зокрема матеріали, що відображають розвиток управлінської науки в розрізі конкретних періодів, дають підстави стверджувати, що ці процеси є складні, неоднозначні та суперечливі.

Перспектива подальших досліджень Саме із врахуванням вищенаведених обставин виникає цілком закономірна необхідність продовження подальших глибоких досліджень функціонування складових науки управління як у сучасних умовах, так і на перспективу.

\section{References}

"Rol i znachennia naukovoi spadshchyny M. TuhanBaranovskoho u rozvytku suchasnoi ekonomichnoi nauky" (2015). Materialy kruhloho stolu (in Ukrainian).

Khmil, F.I. (2003). Osnovy menedzhmentu. Pidruchnyk. K.: Akademvydav (in Ukrainian).

Martynenko, M.M. (2005). Osnovy menedzhmentu: Pidruchnyk. K.: Karavela (in Ukrainian).

Mochernyi, S.V. (2000). Ekonomichna entsyklopediia: U trokh tomakh. T.1. K.: Vydav-nychyi tsentr "Akademiia" (in Ukrainian).

Ostafiichuk, V.F. (2006). Istoriia Ukrainy: Suchasne bachennia: Navch. posib 3-tie vyd., pererob i dop. K.: Znannia - Pres (in Ukrainian).

Ukrainski kooperatory (2001). Istorychni narysy. Knyha II. Lviv: Vyd-vo Lvivskoi komertsiinoi akademii (in Ukrainian).

Zavadskyi, Y.S. (1998). Menedzhment: Management. T.1. Vyd. 2-he. K.: Ukrainsko-finskyi instytut menedzh-mentu i biznesu (in Ukrainian). 